\title{
CONTINUITY AND CHANGE IN TRINIDADIAN TOPONYMS
}

The practice of bestowing names on places as a mark of identification is a time-honoured one which appears in all societies, including primitive ones. It is only natural, in any given society, for such names normally to derive from the language of the speech community concerned. Because of this inescapable link between toponyms and language, place-names can provide interesting insights into linguistic history - and indeed into other aspects of history - and their study is particularly valuable for early periods when more common methods of historical investigation may be inapplicable. Patterns of migration, settlement and colonization may, for example, be reflected in toponyms; and a close study of a map of Trinidad provides useful and interesting clues to the island's demographic history as evidenced in the varied place-names left behind by the different linguistic groups who, over the centuries, have come to compose this traditionally polyglot, multiracial society. However, the complex demographic history of the island has introduced complicating factors, for the coexistence of different languages in the island as well as the superimposition of one language over another (or others) has at times obscured the true origins of a particular toponym. And just as today much of Trinidad's population is a blend of various ethnic groups, so too its toponyms not only reflect varied linguistic traditions but at times represent curious mergers of these traditions.

Trinidad is, by any standard, a particularly fertile field of study as far as place-names are concerned. A quick glance at a map reveals the diversity of the linguistic provenance of toponyms such as:

1 Guanapo, Cumana, Arouca, Caura (Amerindian-Carib and Arawak)

2 Diego Martin, San Fernando, La Brea (Spanish)

3 Ste. Madeleine, Sans Souci, Pointe-à-Pierre (French)

4 Mandingo, Sierra Leone (African)

5 Fyzabad, Nepal, Barrackpore (East Indian)

6 Freeport, Fullerton (English)

Because the last three groups present little or no difficulty and are easily recognizable for what they are, this paper will be restricted to a consideration of the first three, which present unexpected problems. 
Discovered in 1498 by Columbus on his Third Voyage, Trinidad was a Spanish possession until 1797 when it passed into British hands, and it remained British until Independence was granted to it in 1962. But these scant historical facts concerning the island's history tell us little of its demographic and linguistic diversity. In the West Indian islands, for example Barbados and Antigua, the mere fact of colonization by a metropolitan power and the subsequent implantation of the relevant colonial languages frequently led to the almost complete obliteration of all toponyms of other linguistic provenance by those of the superstrate language. But this did not happen in a generalized way in Trinidad where colonial history provides us with the merest hint of the exceedingly complex overall picture. What seems strange at first glance is that, despite the fact that the island ceased to be a Spanish possession over 150 years ago, that during most of the modern period the official language of the island has been English, and that the island never was a French colony, there still remains in modern Trinidad such a plethora of Amerindian, Spanish and French toponyms which generally date to Pre-British days. This is an unusual situation, given the more generalized tendency in the English-speaking Caribbean for English toponyms to predominate, and more especially, for aboriginal names to disappear. It is true that in most of the islands certain isolated place-names from substrate languages have managed to survive, but in the case of Trinidad such survivals, especially those of Amerindian provenance, are disproportionately high.

The retention of Amerindian names appears to be ascribable, at least in part, to the nature of colonization and the extent of settlement in the island during the pre-nineteenth century period. The Spaniards arrived in Trinidad to find it peopled by tribes of different linguistic stocks - Arawakan and Cariban ${ }^{1}$. Starting with Columbus, the Spaniards proceeded to replace indigenous toponyms with Spanish ones, a procedure characteristic of colonial regimes. According to tradition, Columbus had dedicated his Third Voyage to the Holy Trinity, a dedication which must have assumed the proportions of prophetic foresight when the first land he saw happened coincidentally to be a group of three hills in the south-eastern part of the newly discovered island which he called La Trinidad. This new Spanish-derived name thus replaced the Arawakans Kaeri, a name which, unfortunately, has nothing to do with the picturesque translation which has been popularly accorded it "Land of the Humming-bird", since it 
prosaically means simply 'island', having as cognates the forms cayo, key, cay, which appear elsewhere in the Caribbean ${ }^{2}$.

On this Voyage Columbus and his crew also named certain coastal regions that they passed. Among them is Galera, the name they gave to the south-eastern tip of the island, but this name has since been applied to the north-eastern point, the names Galera and Galeota having been transposed ${ }^{3}$. But on this first exploratory visit to the island the Spaniards did not leave many Spanish place-names behind, and of those that they left, some have survived either in the original form, e.g. Galera, or in a calqued form, Boca del Dragón and Boca de la Sierpe being today The Dragon's and the Serpent's Mouths. Others were subsequently replaced e.g. Golfo de la Ballena, which gave way to Golfo de Paria, whence Gulf of Paria.

But for most of the 300 years of Spanish rule, once it had proved not to yield the much coveted gold, Trinidad was left to lie in a state of neglect, while the Spaniards kept their gaze steadfastly fixed on the fabled treasures of El Dorado on the continent. As a result, the Colony languished in an undeveloped and unexploited state. During the entire period of Spanish rule, few Spanish settlements were created, and at least before 1783 , a date which marks the turning-point in the island's development, apart from the capital, San José de Oruña (St. Joseph) and its port, Puerto (de) España (Port-of-Spain), the only other forms of "organized living" were to be found in the Indian missions ${ }^{4}$. These missions generally received Saints' names, but it is noteworthy that these names were usually juxtaposed to pre-existent Amerindian ones, hence Santa Ana de la Sabaneta (Savonetta), Nuestra Sen̂ora de la Anunciación de Sabana Grande (Savana Grande and later Princes Town), La Purísma Conceptción de Nuestra Sen̂̀ora de Naparima (Naparima and San Fernando).

Through the Missions the Amerindians became hispanicized, and certainly by the early nineteenth century, and probably long before then, had lost all knowledge of their own languages and had become completely monolingual Spanish speakers ${ }^{5}$. But despite the hispanicization of the Amerindians, because of the limited development of the island, many of the toponyms of Amerindian provenance remained intact. Before the Amerindians lost their own languages, there must have existed a period of bilingualism; this no doubt facilitated the passage of Amerindian toponyms into Spanish. The complete assimilation of these into the superstrate language is reflected in the fact that many such place-names frequently incorporate morphological elements 
(e.g. suffixes), or syntactic ones (e.g. articles, adjectives) of Spanish origin.

One of the most salient features characterizing Amerindian toponyms, not only in Trinidad, but more generally throughout the Americas, is the way in which they tend so signify some natural feature - topographical, faunal or floral - and were originally simply appellatives or common nouns which eventually came to be elevated to the status of proper names 6 . There is abundant evidence for this generalized claim in Trinidad. Occasionally a tribal name appears as a place-name: Cumana (found in both the north-east and the north-west of the island) < Cumanagoto, a Carib tribe, goto being the terminal suffix of many Cariban tribal names ${ }^{7}$, and Tamana $<$ Tamanaco, is the name of another Carib tribe $^{8}$. But much more generalized is the tendency for Amerindian toponyms to represent the names of plants, trees, animals etc. Apart from the linguistic assimilation of the Amerindians, the preservation of these aboriginal forms must have been further helped by the conditions in which the Spaniards found themselves; faced with a completely new and exotic world of flora and fauna, they frequently adopted the Amerindian designations and incorporated them into their lexis. The chances of survival of these new lexical items were increased by the fact that there were no Spanish equivalents with which they came into conflict, but perhaps, more important to their survival was the fact that more than half of the island's population was Amerindian for most of the Spanish colonial period 9 and such Amerindian words and place-names as there were became firmly entrenched.

I have indicated above that a study of these Amerindian placenames reveals the presence in the island of tribes of both Arawakan and Cariban stock. But this statement deserves some qualification, since it is possible to argue that these toponyms could have entered the island in the nineteenth century with immigrants from Venezuela 10 . It is perfectly legitimate to sound a warning note about using all Amerindian toponyms in Trini$\mathrm{dad}$ as undisputable evidence of the patterns of pre-Columbian settlement in the island, for unless there is clear documentation to the contrary such as is found on early maps, it is possible to suppose that these names may be of more recent origin and may have been brought from the mainland with Venezuelan immigrants, whose Spanish vocabulary included loan-words from both Arawakan and Cariban languages. Hence the Carib word charo T.E.11 'moussara' (Byrsonima coriacea), figures in the 
designation Los Charros, a village which lies in what is well known to be Arawak country and is near the excavated sites of Erin and Palo Seco. This does not necessarily mean that Los Charros ever was place of Carib habitation. The noun charo passed generally into the Spanish vocabulary of the island as of Venezuela and is therefore no evidence of occupation by the Caribs. There are many other similar cases.

However, there are some significant names of Carib provenance which do not belong to this category and which may reasonably be advanced as evidence of Carib settlement. Interestingly, such names tend to appear in the North of the island and it is precisely in this area that historians and chroniclers have indicated the presence during the early period of Carib rather than Arawak inhabitants 12 . For example, as has already been mentioned the names Cumana and Tamana are not simple appellatives but both derive from Carib tribal names, Cumanagoto and Tamanaco ${ }^{13}$, and in fact the T. Sp. name for Tamana remains Tamanaco to the present day. These names also appear in Venezuela but they could not have been introduced by the nineteenth century Venezuelan immigrants since they were to be found in Trinidad before that time and appear in early documents ${ }^{14}$ and maps. Also, it is most improbable that the Arawaks would have used tribe-names of $\mathrm{Ca}$ riban provenance to designate their settlements, given the traditional hostility between the two groups. Furthermore, the name Tamanaco has religious and cultural connotations in Amerindian mythology and is associated with a Noah's Ark type of story of the Judeo-Christian biblical tradition. For, according to Humboldt, when the Tamanacos are asked how the human race survived the great deluge, which, according to their religion, as in so many others, is supposed to have occurred at some remote date, they claim that "a man and a woman saved themselves on a high mountain, called Tamanacu ...; and casting behind them over their heads, the fruits of the mauritia (moriche) palm-tree, they say the seeds contained in those fruits produced men and women who repeopled the earth". 15

Other Carib place-names which derive not simply from appellatives which might have belonged to the general reservoir of Amerindian lexical items in Spanish, but which have some further significance indicative of more direct and specific Carib links are:

Mucurapo < Cumucurapo - This name betrays a Cariban morphological form, apo meaning 'place of', 'home of', and 
cumaca'silk-cotton tree' 16 .

Salybia and Salibea - Breton gives Chaleibe as the Island Carib name for Trinidad. It is true that Island Carib is basically Arawakan, but as we have already seen, the Arawakan name for Trinidad was Kaeri, and Chaleibe must have been the Cariban designation, which survived 17 .

Tunapuna - This name comprises two syntactical elements of Cariban provenance, tona, 'water', 'river', pona, 'on, upon', hence 'on the river' 18 .

It is possible that California and Carapichaima are also Carib in origin, Calliponau being the term generally applied to the Caribspeaking tribes of the Antilles 19 , and Chayma being the name of a Carib tribe 20 .

It is also significant that in the North there are, more than elsewhere, toponyms deriving from Carib names for trees, plants and birds, and while these are not of themselves conclusive proof, they do help to reinforce the theory of Carib occupation in Northern Trinidad. Some of these names are:

Guanapo, 'grass'21

Cumaca, 'silk-cotton tree', Ceiba pentandra

Cunapo, 'red mangrove', Rhizophora mangle

Cunupia, T.E. 'mardi gras', Renealmia sylvestris

Cachipa, T.E. 'balisier', Heliconia sp.

Chaguaramas, T.E. 'palmiste palm', Oreodoxa oleracea

Toco, Morisonia americana

(El) Tucuche, 'humming-bird'

The last-mentioned example shows the noun used in conjunction with the Spanish definite article, indicating the incorporation of the lexical item into the Spanish language. Several other similar toponyms exist. Among them are:

Los Charros

La Canoa

La Seiva, 'silk-cotton tree' (Seiva $<$ Ceiba is Arawakan as opposed to the Cariban cumaca)

Sometimes the Spanish element is a form other than the article and may be an adjective or another noun:

Brasso Caparo, brasso < brazo 'arm' of a river, and caparo, a type of monkey, Lagothrix humboldtii

Cerro Aripo and Cerro Oropuche, Cerro, 'hill, mountain'

Gran Couva

Savana Grande

Vega de Oropuche 
Spanish transformative suffixes are also similarly attached to Amerindian nouns to create other hybrid forms. One of the most productive suffixes thus used is -al, which also appears with great frequency in the true Spanish place-names. The -al suffix may fulfil different semantic functions, and in the toponyms of Trinidad, we see it serving as a morpheme to form a collective noun indicating 'a place of abundance of' e.g. Arenal, 'sandy beach', Cangrejal, 'a place where crabs abound'. It may therefore indicate 'a growth of trees, a grove', Naranjal, 'an orange grove'.

In the following examples which show the Spanish -al suffix attached to nouns of Ameridian origin, no attempt is made to distinguish Carib from Arawak, since most if not all of them, passed generally into Trinidadian Spanish and the distinction is therefore not meaningful for this study.

Bejucal, bejuco 'liane'

Cachipal, cachipa T.E. 'balisier', Heliconia sp.

Carapal, carapa T.E. 'crapaud', Carapa guianensis

Mamural, mamure T.E. 'mamoo', Anthurium flexuosum

Timital, timite T.E. 'timite', Manicaria saccifera

Other suffixes are to be found in:

Maturita

Savonetta < Sabaneta, T.E. 'savonette', Lonchocarpus sericeus

Tabaquite $<$ Tabaquito, 'an unidentified plant'.

In some instances, however, the Amerindian name comes down in what is obviously a form adapted to suit Spanish phonetic habits but with no further change. Some of these may subsequently have been modified by French or English phonetic patterns:

Arima

Cocorite, T.E. 'cocorite palm', Maximiliana elegans

Icacos, T.E. 'fat-pork', a tree and its fruit, Chrysobalanus icaco

Tacarigua, T.E. 'bois flot', Ochroma lagopus

Tairico, 'rice grackle', Scaphidura oryzivora oryzivora ${ }^{22}$

The way in which names were sometimes modified by French and English influence is not restricted to those of Amerindian origin, but also applies to bona fide Spanish names; these were often affected by French influence to the extent that a significant number of toponyms, today popularly believed to be French are to be traced to Spanish origins.

What is surprising is that because of the profound and all-pervasive French influence on all aspects of the island's history (toponymy is but one facet of this), one is tempted to forget the fact 
that the island was not at any time a French possession. We have seen the insubstantial nature of Spanish colonization and settlement in the island and the following statistics pertinent to the year 1778 clearly illustrate this: 444 whites -225 slaves -939 free coloured - 1824 Amerindians 23.

It was only in the last quarter of the eighteenth century that the Spanish Crown finally decided to attempt to develop the island and a serious effort was made to woo colonists to this virgin territory. It is in response to this that the island found itself inundated with a new, largely French, immigrant population which was ultimately responsible for transforming all aspects of the life of the island - agricultural, economic, socio-cultural and linguistic. Except for government, the island became virtually French, and this anomalous situation is well described by Borde, the principal historian of Spanish Trinidad, who sums up the far-reaching and all-embracing influence that the new colonists had on the island: "'Sauf les troupes et les hauts fonctionnaires, on n'y voyait que des colons français parmi lesquels un petit nombre d'Espagnols et de rares Irlandais et Anglais se trouvaient comme noyés. Moeurs, coutumes, langage, tout y était français" 24 .

The lingua franca of the island's motley population became French Creole (known locally as Patois), and the island's Spanishspeakers as well as its other linguistic groups also acquired this lingua franca that had been brought in by the new colonists. No other language - not even English - has left so lasting and profound an imprint on Spanish and Amerindian toponyms as have French and French Creole. The prestige and predominance enjoyed by these superstrate languages during the closing years of the eighteenth and for most of the nineteenth century are therefore significant: while these languages no doubt contributed toponyms of French origin, it is also clear that many names which at first glance seem to be French, do not originally derive from that language at all, but represent gallicization of pre-existent Spanish or Amerindian models.

There are instances in which the influence of the French language operates only on a phonetic level and so instead of the Spanish pronunciation of San Juan which is [ san xwan ] or [ san hwan ] the local pronunciation of this name is [ sầ wồ ] or [ sầ wầ]. French phonetic patterns therefore frequently replace these of Spanish. This is particularly true in the case of Spanish names ending in a final vowel, it being general for such final vowels to be lost in all types of Spanish loan-words in their passage through French and French Creole into English ${ }^{25}$. Hence we have the fol- 
lowing forms:

La Lune for la Luna 26

Marac for Maraca (the form Maracas is also used to designate another place)

La Brea retains the Spanish spelling but is pronounced after the . French fashion with a silent final $-a$

Laventille for La Ventilla

Matelot for Matalote (this name appears as Matalote on Churruca's Map, but it could be a corruption of an Amerindian form)

In some examples, the spelling and/or pronunciation may be affected. For instance Cuba of the early maps becomes and remains Couva; similarly Arauca $>$ Arouca, and Caura $>$ Coora 27. At times the gallicized form of a Spanish original remains as an acceptable French form from which it is undistinguishable e.g. La Lune, but this is not necessarily the case. Hence San Francisco becomes San Francique (French St. François). One writer dubs the form Francique "a curiosity" and lists it as a French name 28 , but it is perfectly clear that it is a French-influenced Spanish name, if one bears in mind the fact that with the fall of the syllable final -s which is characteristic of Trinidadian, and indeed Caribbean Spanish, the resulting Spanish form is Francico which subsequently loses its final - $o$ because of French influence. Similarly Punta Gorda 'Fat Point' (distinguished from Punta Delgada 'Thin Point') becomes the French Pointe Gourde, thereby losing its semantic significance, while the currently used form Laventille, which is so French in appearance, does not reveal at first glance the original significance of the Spanish toponym La Ventilla 29.

But there are other less easily discernible ways in which French influence has managed to transform toponyms. Lavapies, with the loss of final -s, becomes Lavapie, whence T.E. Washfoot, is a descriptive compound which illustrates the functional use to which a stream which bears this name was put. But by popular etymology it has become and remains Lavapierre.

Blanchisseuse, a perfectly acceptable French word, appears to be clearly a French name, its pronunciation being due to French Creole phonetic patterns [blãšišęz]. But this toponym is undisputabably Spanish in origin, the T. Sp. name being Blanquisel (Blanquizal(es)), 'chalk pit'. This descriptive name appears elsewhere in the island, where it retains the Spanish form as Los Blanquizales, and Blanquiares. But already in the nineteenth 
century the name of the coastal village in the North had been corrupted to the form Blanchisseuse since Kingsley makes the following pertinent comment concerning it: "The Ward of Blanchisseuse, on the North coast, whither we were bound was of old, I understand, called Blanchi Sali, or something to that effect, signifying the white cliffs. The French settlers degraded the name to its present form, and that so hopelessly, that the other day an old negress in Port-of-Spain puzzled the officer of Crown property by informing him that she wanted to buy a carré in what you call the washerwoman's!' 30 Already in the nineteenth century, therefore, under the influence of French Creole the word had become phonetically transformed and through popular etymology, had acquired a new meaning.

The modern names for the offshore islands, Gasparee and Little Gasparee, present further interesting examples of popular etymology. On the early maps Gasparee appears as Gaspar or Gaspar Grande, and is distinguished from another island of a similar name, but smaller in size, which bore the Spanish diminutive, - illo, hence Gasparillo. Alternatively, it appears as Gaspar Chico. However, these names subsequently underwent certain changes, Gaspar (or Gaspar Grande) becoming, through French Creole popular etymology, Gasparil, and later Gasparee, owing to the fall of final -1, a phonetic change attributable to French Creole and found elsewhere in the passage of French forms into Trinidadian English ${ }^{31}$. It is possible that the Spanish name Gaspar was confused with the French dendronym gasparil, Esenbeckia spp., which is described as a forest wood like poui, used as bois in stick-fighting 52. Today the Spanish Gaspar Grande is known as Gasparee and the smaller island as Little Gasparee.

The adaptation of Spanish names to French forms sometimes involved calquing rather than simple phonetic adjustment. Today, because of the paucity of early maps, it is frequently difficult to determine whether many of the surviving French names descended from previous Spanish ones, or whether they are original French forms dating back to the French settlement in the last years of the eighteenth century. But the following may be safely assumed to be translated forms since they appear on Crame's Map $(1777)^{3}$, which is one of the few extant maps to antedate the arrival of the French into the island:

Bande de L'Este < Banda del Este.

Carenage $<$ Carenero

Grand Riviere < Río Grande
Pointe-à-Pierre $<$ Punta de Piedras
Pointe Rouge $<$ Punta Colora- da


At times only one part of the name is calqued and the resulting form is a hybrid one :
Morne Cabrite
Gros Tuero R
Morne Diablo
Petit Tuero R.

In the light of the above, it is perhaps surprising that some Spanish names managed to survive unscathed, but many did, and they persist to the present day unchanged save for the expected phonetic modification they receive through English influence. Many of these names which are now applied to towns and villages were originally estate-names:

$\begin{array}{ll}\text { Aranjuez } & \text { La Puerta } \\ \text { Barataria } & \text { Marabella }<\text { Sp. Marabella } \\ \text { Buen Intento } & \text { Valencia } \\ \text { Buenos Ayres } & \text { Valsayn } \\ \text { El Dorado } & \text { Vistabella. }\end{array}$

But there are others which, like the Amerindian toponyms, are frequently indicative of some particular characteristic:

\begin{tabular}{|c|c|}
\hline Arena & Manzanilla \\
\hline Arrecife & Palo Seco \\
\hline Barro R. & Penal $<$ Sp. Penầl (The form \\
\hline Blanquizales (Lagoon) & with $\hat{\mathrm{n}}$ appears on some \\
\hline $\begin{array}{c}\text { Brasso } \\
\text { river) }\end{array}$ Sp. brazo (of a & $\begin{array}{l}\text { maps and there are still tra- } \\
\text { ces of its presence in the na- }\end{array}$ \\
\hline Brasso Piedra & salized pronunciation (piyal) \\
\hline Brasso Seco & that one sometimes hear \\
\hline Brazil & particularly among olde \\
\hline Cambural & persons) \\
\hline Cangrejal & Piedra Blanca \\
\hline Cascajal & Rancho Quemado \\
\hline Cedros & Sangre Grande (river and \\
\hline $\begin{array}{l}\text { Cocal } \\
\text { El Soldado (Island) }\end{array}$ & town) \\
\hline $\begin{array}{l}\text { El Soldado (Island) } \\
\text { Las Cuevas }\end{array}$ & $\begin{array}{l}\text { Sangre Chiquito (river and } \\
\text { lage) } 33\end{array}$ \\
\hline as Lomas & Tortuga \\
\hline
\end{tabular}

Los Armadillos 
Other original Spanish names have been either wholly or partially translated into English:
Dragon's Mouth
Port-of-Spain
Cangrejos Pt. and Bay
St. Joseph
The Coffee 34
Cape Casa Cruz
The Saddle 35
Entrada Pt.
Point Lisas
Point Parasol
Barrancones Pt.
Quemada Pt.
The Bocas

Several French toponyms survive but these are more easily dealt with in that, apart from their French Creole rather than standard pronunciation, they have undergone little or no change. The names of French settlers are commemorated in some of these placenames:
D'Abadie
Lopinot
Lapeyrouse $<$ La Pérouse
Rousillac

Others are descriptive:
La Carrière
Ravine Sable
Croisée (pronounced)
L'Anse Mitan
[kwéze] after the French
Creole fashion)
Petit l'anse
Granville
Petit Morne
Grand(e) Ravine
Morne Bleu

Other miscellaneous French toponyms include:
Les Frères (Rocks)
Point à Diable
Tête Boeuf
Trou Bouilli-Riz Pt. (possibly a corruption of Trou Borelli)
Trou Borelli
Trou Tazard

However, a substantial number of French toponyms originate in estate names, many of which are idyllic-sounding and redolent of the civilized type of society that the French settlers attempted to recreate in their adopted home. Among these are:
Bonne Aventure
Mon Repos
Champs Elysées
Esperance
Terre Promise

It is appropriate to conclude with these toponyms which, by evoking "Elysian Fields" and "Promised Lands" are far removed 
from the more prosaic process of naming characteristic of the Trinidad's first inhabitants. But the island's French place-names do not only reflect a more developed and settled society; some of the superficially French-sounding ones, like Blanchisseuse, illustrate the profound influence the French colonists had on the island. A study of this influence, as of the coexistence of toponyms of such varied and interacting linguistic traditions reveals yet another facet of the demographic and linguistic complexity of the island, a facet which is characterized by the opposing yet harmonising tendencies of continuity and change, of tradition and innovation.

\section{APPENDIX}

PRESENT-DAY TRINIDADIAN TOPONYMS OF AMERINDIAN, SPANISH AND FRENCH ORIGIN

This list is meant to be representative but is not exhaustive. Unless there are indications to the contrary these names are of towns, villages or hamlets.

\section{AMERINDIAN NAMES 38}

Arima, Hyarima, the name of an Nepuyo chief. 39

Arouca, Arauca, an Arawakan tribal name.

Atagual ${ }^{*}$

Bejucal, bejuco 'liane'.

(Brasso) Caparo, type of monkey, Lagothrix humboldtii.

Cachipa, T. E. 'balisier', Heliconia sp.

Cachipal, cf. Cachipa.

Caigual, caigua an unidentified fruit.

California, cf. p. 128.

Carapal, carapa T. E. 'crapaud', Carapa guianensis.

Carapichaima, cf. p. 128.

Carapo, cf. Carapal above.

Caratal, carata, T. E. 'carat palm', Sabal sp.

Caroni, also a Venezuelan place-name.

Caura, also a Venezuelan place-name.

(Cerro) Aripo (Mt.)

(Cerro) Oropuche (Mt.)

Chaguanas, Chaguanes, tribal name.

Chaguaramal, chaguaramo T.E. 'palmiste palm', Oreodoxa oleracea.

Chaguaramas, cf. Chaguaramal.

Cipero (River)

Cocorite, cucurito T.E. 'cocorite palm', Maximiliana elegans.

Coora, variant for Caura, cf. p. 131.

Corozal, corozo T.E. 'banga palm' Acrocomia.

Coryal, corí, curí T.E. 'agouí', Dasyprocta aguti. 
Couva, cf. p. 131.

Cumaca 'silk-cotton tree', Ceiba pentandra.

Cumana, cf. pp. $126+127$.

Cunapo, 'red mangrove', Rhizophora mangle.

Cunupia, T.A. 'mardi gras', Renealmia sylvestris.

Curepe, also a Venezuelan place-name.

Curucayo, 'incense tree', Copaifera officinalis or Protium guianense.

(El) Mamo (River)

(El) Tucuche (Mt.) cf. p. 128.

Gran Couva, cf. Couva above.

Guaico, 'type of reed'.

Guamal, guamo T.E. 'pois doux', Inga faeculifera.

Guanapo, 'grass'.

Guapo, plant with a tuberous root.

Guayaguayare

Icacos, icaco T.E. 'fat pork', Chrysobalanus icaco.

(La) Canoa (River)

La Seiva, seiba 'silk cotton tree', Ceiba pentandra.

Los Charros, charo 'moussara', Byrsonima coriacea.

Los Iros*

Mamural T.E. 'mamoo', Carludovica palmata.

Maqueripe*

Matura*

Maturita*

Mayaro*

Mayo, name of a plant, Bromelia pinguin.

Morichal, moriche T.E. 'moriche palm', Mauritia flexuosa.

Moruga

Mucurapo, formerly Cumucurapo.

Naparima, formerly Anna Parima, 'one hill'. 40

Nariva (River), given as Narigua in a seventeenth century document. 41

Ortoire, formerly Guataro. 41

Piarco

Poole (River), formerly Pure 42 .

Pouisal, poui, Tecoma serratifolia.

Quinam *

Savana Grande (Ward)

Salibea, cf. p. 128.

Salybia, cf. p. 128.

Savonetta T.E. 'savonette', Lonchocarpus Sericeus.

Siparia*

Tabaquite, an unidentified plant.

Tacarib*

Tacarigua T.E. 'bois flot', Ochroma lagopus.

Tairico 'rice grackle', Scaphidura oryzivora oryzivora.

Talparo, taparo, 'calabash', Crescentia cucurbitina.

Tamana, cf. pp. $126+127$.

Timital, timite T.E. 'timite', Manicaria saccifera.

Toco, Morisonia americana.

Tumpuna

Tunapuna, cf. p. 128

Yarra*

Vega de Oropuche. 
SPANISH NAMES 43

\begin{tabular}{|c|c|}
\hline $\begin{array}{l}\text { Arena } 44 \text { (River + Reserve) } \\
\text { Aranjuez }\end{array}$ & $\begin{array}{l}\text { Lavapies (also Lavapierre and Wash- } \\
\text { foot) }\end{array}$ \\
\hline Arrecife (also Reef's Point) & Lengua \\
\hline Balandra 45 & Limon \\
\hline Balmain & Los Armadillos \\
\hline Barataria & Los Bajos \\
\hline Barro (River) & Los Gallos (Point) \\
\hline Blaquizales (Lagoon) & Madamas 46 \\
\hline Brasso $<\mathrm{Sp}$. brazo (of a river) & Majorca (Island) \\
\hline $\begin{array}{l}\text { Brasso Piedra } \\
\text { Brasso Seco }\end{array}$ & $\begin{array}{l}\text { Manzanilla, 'manchioneel', Hippo- } \\
\text { mane mancinella. }\end{array}$ \\
\hline Brasso Venado & Marabella $<$ Sp. Marbella. \\
\hline Brazil & Melajo < T. Sp. gato melado, Muste- \\
\hline Buen Intento & la barbara. \\
\hline Buenos Ayres & Minorca (Island) \\
\hline Cambural & Monos (an offshore island) \\
\hline Cangrejal & Montserrat (W ard) \\
\hline $\begin{array}{l}\text { Cantaro (pronounced with the stress } \\
\text { on the penultimate syllable, could } \\
\text { this be Amerindian?). }\end{array}$ & $\begin{array}{l}\text { Mundo Nuevo } \\
\text { Naranjo } \\
\text { Palo Seco }\end{array}$ \\
\hline Carrera (an offshore island) & Patos (an offshore island) \\
\hline $\begin{array}{l}\text { Cascadura (River), cáscara dura, 'a } \\
\text { type of fish', Callichthys thoraca- } \\
\text { tus. }\end{array}$ & $\begin{array}{l}\text { Penal } \\
\text { Piedra Blanca } \\
\text { Platanal }\end{array}$ \\
\hline Cascajal & Puerto Grande \\
\hline Cedros & Punta Blanca \\
\hline Cocal & Punta del Morro \\
\hline Diego Martin & Punta Tablas \\
\hline El Dorado & Quebrada Grande (River) \\
\hline El Socorro & Rancho Quemado \\
\hline El Soldado (a rock in the Serpent's & Rio Claro \\
\hline Mouth) & San Fernando \\
\hline $\begin{array}{l}\text { Farallon (a rock off the San Fernando } \\
\text { Coast) }\end{array}$ & $\begin{array}{l}\text { San Juan } \\
\text { San Rafael }\end{array}$ \\
\hline Galeota (Point) & Sangre Chiquito (River and village) \\
\hline Galera (Point) & Sangre Grande (River and town) \\
\hline Gasparillo & Santa Cruz \\
\hline $\begin{array}{l}\text { Gran Boca (largest passage of the Dra- } \\
\text { gons Mouths) }\end{array}$ & $\begin{array}{l}\text { Tembladora } \\
\text { Teteron }\end{array}$ \\
\hline Huevos (an offshore island) & Tortuga \\
\hline La Pastora & Trinidad \\
\hline La Puerta & Tuero (River) \\
\hline La Veronica & $\begin{array}{l}\text { Valencia } \\
\text { Valsayn }\end{array}$ \\
\hline $\begin{array}{l}\text { Las Cuevas } \\
\text { Las Lomas }\end{array}$ & Vistabella \\
\hline as Tab & \\
\hline
\end{tabular}


fully or partially translated into English

Alcatraz Point

Barrancones Point

Cangrejos Point and Bay

Cape Casa Cruz

Cape Cola

Corral Point

Diego Island

Dragon's Mouths, Sp. Bocas del Dra-

gon.

Entrada Point

Esperanza Bay

Point Fortin

Point Lisas

Point Morro
Point Paloma

Point Parasol

Point Playas

Port-of-Spain < Sp. Puerto (de) Espan̂̀a.

Quemada Point

Reef's Point

Shark River (Rio Tiburón on Crame's Map)

St. Augustine

St. Joseph

Serpent's Mouth

The Bocas.

translated fully or partially into French or influenced by French popular etymology

Bande de l'Est < Sp. Banda del Este.

Bateau (Point)

Blanchisseuse $<$ Sp. Blanquizales.

Carenage Sp. Carenero on early maps.

Fronton de Salive

Gasparee (Island)

Grand Riviere

Gros Tuero (River)

La Brea (pronounced La bre)

La Lune

Lavapierre $<\mathrm{Sp}$. Lavapies.
Laventille $<\mathrm{Sp}$. La Ventille

Matelot (Matalote on Crame's and Churruca's Maps)

Morne Cabrite

Morne Diablo

Point-a-Pierre (Punta de Piedra on Crame's Map)

Petit Tuero (River)

Pointe Gourde

Point Fortin

Point Rouge (Punta Colorada on Crame's Map)

\section{FRENCH NAMES}

Bel Air

Belle Vue

Biche

Boissiere

Bonne Aventure

Bourg Mulatresse

Champs Elysees

Champ Fleurs

Chaudière (River)

Croisée

D'Abadie

Esperance

Fillette 47

Grand Anse

Grand Basse
Grand(e) Ravine

Granville

La Carriere

L'Anse Mitan

Lapeyrouse

La Fortune

La Romain

Les Efforts

Les Freres

Lopinot

Malgre Tout

Mon Repos

Morne Bleu

Petit Bourg

Petit l'Anse
Petit Morne

Petit Trou

Petit Riviere

Pointe à Diable

Pointe Sable

Sans Souci

Rousillac

Sante Madeleine

Tête-à-boeuf

Trois Roches

Trou Borelli

Trou Bouilli-Riz (Point)

Trou Tazard 


\section{NOTES}

1 Despite the view expressed by some authorities that the "Caribs never at any time, actually inhabited Trinidad", toponymic evidence given below appears to attest the presence of Carib settlement on Trinidadian soil. The above quotation is from J.A. Bullbrook "The Carib-Arawak controversy", Shell Trinidad, March 1957, p. 7.

2 The attractive appellation "Land of the Humming-bird", supposedly a translation of Iëre (Kaeri) must be justified on ornithological and not linguistic grounds. Cf. my article "Notes on Iëre, the Amerindian name for Trinidad", Caribbean Quarterly, Vol 13, 1967, pp. 45-51.

3 Hence today the name Galera is used to designate the north-eastern Point; the former Galera Point is now Galeota Point. This switch must have occurred after 1637 and befor 1803 since a document bearing the former date indicates that Galera was still being used for the south-eastern point, T.H.S, Publications, No. 102. The Council of $W$ ar to the King, 10 Nov. 1637, Add. Mss. 36324 B.M. But Capt. Columbine's Map (1803) already shows the names as they are used today. It is to be noted, however, that despite the 1637 naming of these points according to their original designations, the confusion surrounding them began as early as the sixteenth century. Cf. R.W. Thompson, "Pre-British place-names in Trinidad", De West-Indische Gids, Vol. 39, 1959, p. 156.

The following are the early maps of Trinidad which were consulted for this study:

Cosmé Damian de Churruca, Carta esférica de la Isla de Trinidad,1793, consulted in the collection of the late Mr. T.C. Cambridge, Port-of-Spain.

Capt. Columbine, [Map of Trinidad], 1803, seen in the collection of the late Mr. T.C. Cambridge.

Agustín Crame, [Map of Trinidad], 1777, B.M. Add. Mss. $17645 f$ f.

Plano de ysla Trinidad, Golfo Triste, y Costa Occidental del Río Orinoco, 1795-96. B.M. Add. Mss. 17645 g.

4 James Millette, The Genesis of Crown Colony Government: Trinidad, 1783-1810, (Port-of-Spain, 1970), p. 6. The scant penetration into the island by the Spaniards is reflected in the fact that in the early period Spanish toponyms are confined largely to coastal features e.g. rivers. Cf. Francisco Morales Padrón, Anuario de Estudios Americanos, Vol. 14, 1959, p. 120.

5 J.E. Alexander, Translantic Sketches, (London, 1833), Vol. I, p. 224.

6 Cf. Nils Holmer, "Indian place-names in South America and the Antilles" I, Names, Vol. 8, 1960, p. 138.

7 C. de Goeje, Etudes linguistiques caribes, Vol. II (Amsterdam, 1946), p. 56.

8 Cf. Note 13 below.

9 Jesse Noel, Trinidad, Provincia de Venezuela, (Caracas, 1972), p. 93 and p. 94. 
10 From 1810 onwards Venezuelan immigrants began to enter the island. In the early years they were largely political refugees, though later on they came to the island as peón labour.

11 T.E. here and elsewhere stands for Trinidadian English, and T. Sp. for Trinidadian Spanish. Although the official language of the country has been English for over a century and a half, the Spanish language is still spoken by a few people in the remoter rural areas.

12 Among them Sir Walter Raleigh, The Discoverie of the Large and Bewtiful Empire of Guiana, ed. V.T. Harlow, (London, 1928), p. 12 and p. 30; cf. also Sven Lovén, Origins of the Tainan Culture, (Göteborg, 1935), p. 41.

13 For the Cariban affiliation of these two tribes cf. Daniel G. Brinton, La raza americana, trans. A.G. Perry, (Buenos Aires, 1946), p. 237.

14 Reference is made to the Cerro de Tamanaco in a document of 1699 , Archivo General de Indias, Audiencia de Santo Domingo, Autos seguidos en la Isla de la Trinidad contra los indios de la misión de San Francisco de la Are$n a$, Legajo 582.

A Mission was established at Cumana in the eighteenth century. L.A.A. De Verteuil, Trinidad, its Geography, Natural Resources, Administration, Present Condition and Prospects, 2nd. ed. (London, Paris, New York, 1884), p. 443.

15 A. von Humboldt, Personal Narrative of Travel to the Equinoctial Regions of America during the years 1799-1804 with A. de Bonpland, trans. Thomasina Ross, (London, 1852), Vol. II, p. 182.

16 For the Carib origin of Cumaca, cf. C. Ahlbrinck, Encyclopaedie der Karaiben, (Amsterdam, 1931), p. 235, and H. de Goeje, op. cit., Vol. I, p. 575, for the meaning and function of - $p o,-a p o$, see Ahlbrinck, op. cit. p. 377.

17 Raymond Breton, Dictionnaire carä̈be-français, (Auxerre, 1664), p. 390.

18 De Goeje, op. cit., Vol. II, pp. $64+84$.

19 A. Ballesteros y Beretta, ed. Historia de América, (Barcelona, 1961), p. 788. See also, Humboldt, op. cit., Vol. III, p. 78.

20 Brinton, op. cit., p. 236.

21 The following works have been consulted for establishing the Cariban affiliation of this word and those that follow:

Lisandro Alvarado, Glosario de voces indigenas, (Caracas, 1953).

G. Friederici, Amerikanistisches Wörterbuch, (Hamburg, 1947).

C.H. de Goeje, Etudes linguistiques caribes, Vols. I \& II, (Amsterdam, 1909 \& 1946).

C. Ahlbrinck, Encyclopaedie der Karaïben, (Amsterdam, 1931).

Attempts are made, where possible and appropriate, to give the scientific names of trees, plants etc., along with their English or vernacular equivalents. 
22 A fuller list of Amerindian place-names appears in the Appendix.

23 These figures are taken from a letter from Governor Falquez. Archivo General de Indias, Audiencia de Caracas, Correspondencia con los gobernadores de la Trinidad, Legajo 150.

24 P.G.L. Borde, Histoire de l'île de la Trinidad sous le gouvernement espagnol, (Paris, 1876), Vol. II, p. 263.

25 e.g. T.E. sapat <-Sp. zapata, T.E. sancoche (pronounced with a mute final $-e<$ Sp. sancochol.

26 Thompson (art. cit. p. 157) maintains that this is not necessarily a French or Spanish name. But this coastal hamlet may well be named after the lune or dory, T. Sp. luna, of the fish family Scombridae. See De Verteuil, op. cit., p. 389.

27 This latter form appears in the South, although a village in the Northern hills which has remained Spanish-speaking until the present time retains the original form, Caura.

28 Thompson, art. cit., p. 163.

29 This toponym is generally written La Ventilla in Spanish documents. It is thus given in Josefina Pérez Aparicio, Pérdida de la isla de Trinidad, (Sevilla, 1966), p. 126, and Noel, op. cit., p. 98.

30 Charles Kingsley, At last, (London + New York, 1872), p. 263. See also Thompson, art. cit., p. 163.

31 e.g. Courbaril, the name of a tree > T.E. courbary, Hymenaea courbaril.

32 Andrew Carr, "Pierrot Grenade", Caribbean Quarterly, Vol. 4, 1956, p. 284 , note 3 .

33 Thompson (art. cit., p. 161) considers that in this place-name, if sangre means 'blood', Chiquito (mas.) is unusual. The explanation lies in the fact that we are dealing here with an original hydronym. The gender of these is masculine in Spanish.

34 This name appears in the Spanish form El Café in De Verteuil, op. cit., p. 306.

35 De Verteuil (op. cit. p. 277) gives this name in its Spanish form, La Silla.

36 Given as Grandeville in De Verteuil, op. cit., p. 41.

37 Mitan, French Creole for 'middle', Thompson, art. cit., p. 165. The agglutination of the definite article is frequent in French Creole. Cf. J.J. Thomas, The Theory and Practice of Creole Grammar, (London + Port-otSpain 1969), p. 18. 
38 No attempt is made here to distinguish Arawakan from Cariban toponyms. These Amerindian names include those which have incorporated a Spanish morphological or syntactic element. Where it is possible to isolate the Spanish element this is done by means of brackets. With the exception of those marked " whose origin is suspected to be Amerindian but for which no documentation has been found, and those which are otherwise explained, the names listed appear as Amerindianisms in one or more of the following works:

C. Ahlbrinck, Encyclopaedie der Karaïben, (Amsterdam, 1931).

L. Alvarado, Glosario de voces indígenas de Venezuela, (Caracas, 1953).

R. Breton, Dictionnaire caraïbe-franģais, (Auxerre, 1664).

C. de Goeje, Etudes linguistiques caribes, 2 Vols., (Amsterdam, $1909+$ 1946).

C. de Goeje, The Arawak Language of Guiana, (Amsterdam, 1928).

C. de Goeje, Nouvel examen des langues des Antilles, (Paris, 1939).

G. Friederici, Amerikanistisches Wörterbuch, (Hamburg, 1947).

A. Malaret, Vocabulario de Puerto Rico, (New York, 1955).

A. Malaret, Lexicón de fauna y flora, (Madrid, 1970).

A. Rosenblat, Buenas y malas palabras en el castellano de Venezuela, 2 Vols., (Caracas-Madrid, 1956).

F.J. Santamaría, Dictionario general de americanismos, 3 Vols., (México, 1942).

39 Claud Hollis, A Brief History of Trinidad under the Spanish Crown, (Trinidad + Tobago, 1941), p. 49.

40 Hollis, op. cit., p. 6.

41 Archivo General de Indias, Audiencia de Santo Domingo, Legajo 582.

42 Cf. De Verteuil, op. cit., p. 326.

43 Because the Spanish and French names are more easily understood, only the less obvious ones are explained in terms of their meaning.

44 This could be a corrupted Amerindian form since arina means 'clay' in the Carib languages. De Goeje, Etudes linguistiques, Vol. II, p. 64.

45 This could also be Amerindian; balanna 'la mer' according to Breton, Dictionnaire Caraïbe-Français, Vol. I, p. 67.

46 Thompson (art. cit. p. 157) doubts the Spanish origin of this name and suggests that it might be a corrupted form of an Amerindian name. This is quite possible.

47 Despite its French appearance I suspect, like Thompson, art. cit., p. 164, that this name has probably been influenced by folk etymology. It is probably not French in origin at all.

Mrs. K.M. Laurence

Lecturer in Spanish

University of the West Indies

St. Augustine, Trinidad, W.I 